\title{
Idegenhonos ékszerteknős és mocsári teknős populációk jellegzetességei az Újszegedi Holt-Maroson
}

\author{
Molnár Nóra, Fekete Zsolt és Bokis Alexandra \\ Szegedi Tudományegyetem, Ökológiai Tanszék \\ Szeged, Középfasor 52. \\ e-mail:molnarn@bio.u-szeged.hu
}

\begin{abstract}
Összefoglaló: Szeged belterületén, az Újszegedi Holt-Maroson végeztünk teknős populációs felméréseket 2017. júniustól szeptemberig. A holtágat végigjárva feljegyeztük a napozó teknősök faját és pozícióját. Ezt követően napozó csapdákat helyeztünk ki a holtág 6 pontjára. Célunk volt az idegenhonos teknősök begyüjtése illetve a mocsári teknős populáció felmérése. Minden befogott teknőst lemértünk, leírtuk az esetleges sérüléseiket és a torz páncélformákat. A napozó egyedek felmérésekor 59 mocsári teknőst és 65 idegenhonos teknőst számláltunk. A két és fél hónapos csapdázás során 75 mocsári teknőst és 69 idegenhonos teknőst fogtunk. Az idegenhonos fajok döntő többsége közönséges ékszerteknős. Az ékszerteknősök és mocsári teknősök méreteloszlása eltérő mintázatú. A nőstény ékszerteknősöknél a nagyobb mérettartomány képviselöi voltak többségben, míg a mocsári teknősnél a közepes méretűek domináltak. A sérült egyedek aránya a mocsári teknősöknél magasabb volt (20\%, az ékszerteknősöknél 11,9\%), közülük is a nőstények sérülnek gyakrabban (31,7\%). Ha összevetjük a napozó egyedek felmérését a csapdázás eredményeivel, azt kapjuk, hogy jelentős különbségek adódnak a térbeli eloszlásban.
\end{abstract}

Kulcsszavak: mocsári teknős, ékszerteknős, inváziós faj, méret-eloszlás

\section{Bevezetés}

Az elmúlt évtizedekben a globalizáció hatására nőtt a légi és tengeri áruforgalom, így az egzotikus állatok kereskedelme jelentős méreteket ölt napjainkban, amely elősegíti a nem őshonos fajok megjelenését idegen biotópokban (Arena et al. 2012, Lowe et al. 2000, Vitousek 1997). A fauna idegen fajok megjelenése egy új környezetben komoly hatással lehet az öshonos populációkra. Táplálkozás, szaporodás illetve fertőző betegségek szempontjából ez jelentős változást idézhet elő az adott életközösségben (Huxel 1999, Mooney \& Cleland 2001, Shea \& Chesson 2002). Potenciális veszélyt jelentenek azok a különböző édesvízi teknősfajok az őshonos állományokra, melyeket világszerte importálnak egzotikus házi kedvencként. Az egyik legjelentősebb fajuk a közönséges ékszerteknős (Trachemys 
scripta) Észak-Amerikából származik, kereskedelem révén került Európába. Felelőtlen állattartók gyakran szabadon engedik a megunt ékszerteknősöket természetes vizekben. Magyarországon potenciálisan jelent veszélyt invazív fajként az őshonos növény- és állatvilágra. Élőhely használata nagyon hasonlít a mocsári teknősére (Emys orbicularis), ezért együttes előfordulásuk gyakori. Ilyen esetekben az ékszerteknősök kiszoríthatják élöhelyükről az őshonos mocsári teknősöket (Cadi \& Joly, 2003, 2004). Bizonyos dél- és közép-európai országokban szaporodóképes populációkat hozhat létre (Perez-Santigosa et. al. 2008, Sancho \& Lacomba, 2016). Emiatt 2014-ben felkerült az Európai Unió számára veszélyt jelentő inváziós idegenhonos fajok jegyzékére (1143/2014/EU sz. rendelet).

\section{Anyagok és módszerek}

Szeged belterületén, egy helyi jelentőségű védett területen, az Újszegedi HoltMaroson végeztünk teknős populációs felméréseket. A holtág Szeged város újszegedi városrész frekventált részén terül el mintegy 6 hektár területen. Hossza kb. 4 kilométer átlagos szélessége 10-15 méter, a vízmélység 1-2 méter között változik. Mindkét partján séta- és kerékpárút húzódik. A 2000-es évek elején rehabilitált holtágat a helyi horgászegyesület hasznosítja, évente 15-20 mázsa halat telepítenek. Élőhelyként nagyszámú mocsári teknősnek nyújt otthont. Az utóbbi években megjelentek a Holt-Marosban a díszállatként tartott, és itt szabadon engedett ékszerteknősök is.

2017. június 12-én végigjártuk a Holt-Maros partját, és feljegyeztük a megfigyelt napozó teknősök számát és pozícióját. Ezt követően napozó-csapdákat helyeztünk ki a holtág 6 pontjára, amelyeket 2-3 naponta ellenőriztük. A napozó-csapda olyan élvefogó csapda, ami egy vízfelszínen lebegő PVC keretből, a kerethez csatlakozó felszín alatt helyezkedő drótháló kosárból, valamint a kereten átívelő deszka pallóból áll. A teknősök a pallót használják napozásra, de megzavarás esetén vízbe vetik magukat. Ha a PVC kereten belül esnek a vízbe, akkor onnan már nem tudnak kiszabadulni (Valdeón et al. 2010). A csapdák szeptember 1-ig müködtek. Minden befogott teknőst lemértünk (páncélhossz, szélesség, testtömeg), feljegyeztük a nemüket, esetleges sérüléseiket és a torz páncélformákat. A mocsári teknősöket páncélreszelés módszerével jelöltük: a baloldali szegélypajzsokat reszeltük, mindegyik szegélypajzs a kettes számrendszer egy-egy értékének felel meg, így egyedi sorszámokat kaptak a teknősök. Ezek után a mocsári teknősöket visszaengedtük, az ékszerteknősöket eltávolítottuk az élőhelyről. 


\section{Eredmények és megvitatásuk}

A napozó teknősök felmérésekor 59 mocsári teknőst és 65 idegenhonos teknőst számláltunk. Napozásra leginkább a vízitök levelét használták, valamint vízbe nyúló vagy vízben úszó fatuskókon is napoztak. A vízparton való sütkérezést csak a mocsári teknős egyedeinél figyeltük meg. A két és fél hónapos csapdázás ideje alatt 75 mocsári teknőst (a fogások száma 96 volt) és 69 idegenhonos teknőst fogtunk. Tehát az egymáshoz viszonyított arányuk mindkét megfigyelési módszerrel hasonló.

Az idegenhonos teknősök döntő többsége közönséges ékszerteknős volt, amelynek mindhárom alfaját sikerült befogni (vörösfülü, sárgafülü és Troostékszerteknősöket: Trachemys scripta elegans, T. scripta scripta, T. scripta troostii). Emellett fogtunk 1 kínai csíkosteknőst (Mauremys sinensis) és 1 tarajosteknős fajt (Graptemys sp.). Ha a befogott teknősök egyedszáma mellett megnézzük a biomasszájukat, vagyis a csapdázott egyedek össztömegét is, akkor azt tapasztaljuk, hogy az idegenhonos fajok biomasszája sokkal jelentősebb (idegenhonos teknősök össztömege: 52187 g, a mocsári teknősök össztömege: 30013 g). Ez a testnagyságbeli különbségekből is adódik, de az eltérő méreteloszlás valamint az ivararány különbözősége is okozhatja a jelenséget. Mindez arra utal, hogy bár az egyedszámban nincs jelentős különbség, a testi fölényből adódó előnyök az idegenhonos fajoknak kedveznek. Meghatároztuk az ivararányt a mocsári teknősök és a közönséges ékszerteknősök esetében is. Mindkét fajnál a nőstények domináltak, de az ékszerteknősök esetében kétszer annyi nőstényt fogtunk, mint hímet (nőstény/hím: 2,0 - ékszerteknősök és 1,46-mocsári teknősök). A 22 hím ékszerteknős egyed közül 18 a vörösfülủ alfajhoz tartozott (ez a vörösfülüek közel 44\%-át jelenti), ami azért érdekes, mert az általános vélekedés szerint a fogságban tartott vörösfülü ékszerteknősök túlnyomó többsége nőstény a tenyésztési körülmények miatt (Mali et al. 2015). A sérült egyedek aránya a csapdázott egyedeknél sokkal magasabb volt a mocsári teknősök esetében (20\%), az ékszerteknősöknél ez az arány $11,9 \%$ volt. Ha a sérülések súlyosságát is figyelembe vesszük, akkor is a mocsári teknősök érintettebbek, náluk végtaghiányt, csonka farkat és a páncéltörést, repedést is észleltünk, míg a sérült ékszerteknősök többségénél csak kisebb páncélsérüléseket (karcolásokat, fognyomokat) tapasztaltunk. Ha nemenként vizsgáljuk a sérüléseket, azt láthatjuk, hogy az ékszerteknősöknél hasonló arányban sérültek a hímek és nőstények, a mocsári teknősnél viszont a nőstények sokkal nagyobb arányban $(31,7 \%)$ sérültek, mint a hímek $(7,14 \%)$. Valószínúleg a tojásrakással együtt járó intenzívebb mozgással magyarázható a nőstények sérülékenysége. A két faj egyedei méretben eltérnek. Ezt nemenként megvizsgáltuk, az ékszerteknősök egyedei mind a hímeknél, mind a nőstényeknél nagyobbak (két- 


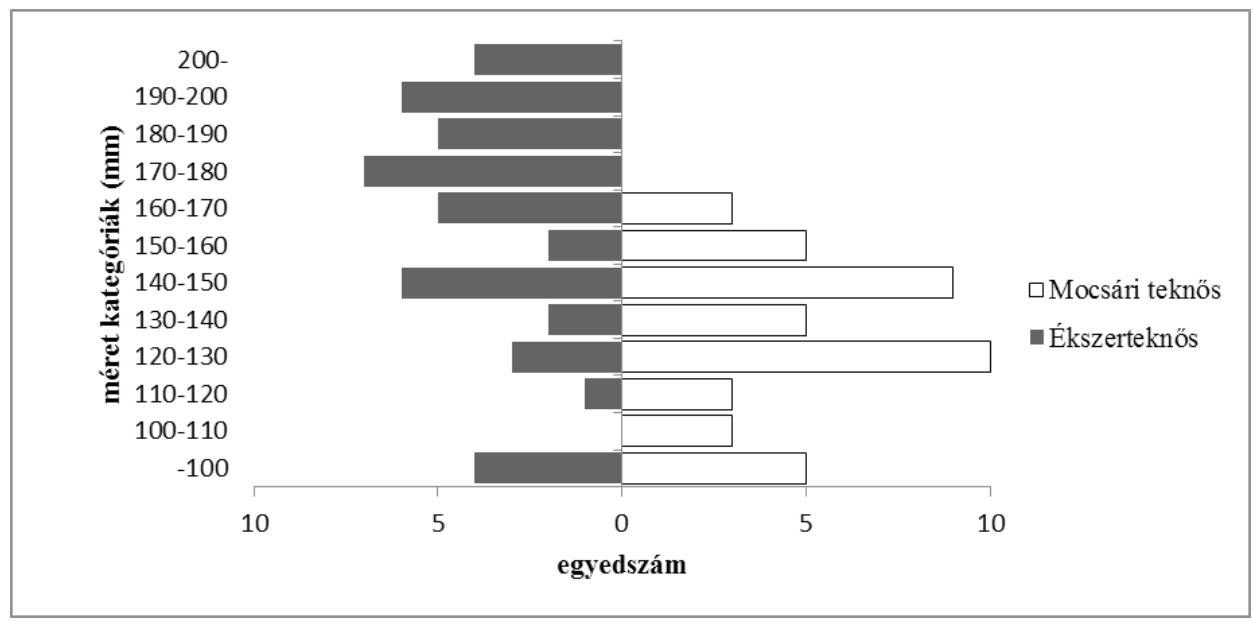

1. ábra: A befogott nőstény teknősök méret kategóriák szerinti gyakorisága a két fajnál a plastron (haspáncél) hossza alapján.

mintás t-próba eredménye mindkét összehasonlításnál: $p<0,001)$. A befogott egyedek méreteloszlását csak a nőstény egyedeknél elemeztük. A mocsári teknősöknél a közepes mérettartományba tartozott a legtöbb egyed, míg az ékszerteknősöknél a nagyobb mérettartomány egyedei voltak többen (1. ábra), de emellett voltak kisméretű egyedek is. Ha összevetjük a napozó egyedek felmérését a csapdázás eredményeivel, azt kapjuk, hogy jelentős különbségek adódnak a térbeli eloszlásban. Az 5-ös, 6-os csapda körzetében (Fö fasor és Derkovits utca közötti szakasz) kevés ékszerteknőst láttunk napozni, viszont a befogott egyedek 70\%-a innen került elő. Itt nem volt igazán alkalmas napozóhely, a mocsári teknősök is föként a partra húzódtak ki napozni. A 3-as és a 4-es csapda vonzáskörzetében (Bérkert utca és Fő fasor közötti szakasz) viszonylag sok ékszerteknőst láttunk napozni, leginkább a vízitök levelét preferálták, de nem sikerült öket megfognunk, mindössze 10 egyed került a csapdákba két és fél hónap alatt. Ebből is látszik, hogy a napozó-csapda ott müködik igazán jól, ahol kevés az alkalmas napozóhely a teknősök számára. A holtág különböző szakaszai eltérő élőhelyi sajátságokkal jellemezhetők, a teknősök számára fontos napozóhelyek tekintetében mindenképpen.

A közönséges ékszerteknős inváziós fajnak számít Európában, egyre több helyen és egyre nagyobb számban jelenik meg föként lakott területekhez közeli vizes élöhelyeken Magyarországon is. Az Újszegedi Holt-Maroson a megfigyelt teknősök fele idegenhonos teknős volt, ami azt jelenti, hogy a megunt házi kedvencek nagy számban kerülnek ide, és az élőhely kedvező számukra hosszútávon is. Az ékszerteknősök testnagyságbeli fölénye előnyt jelenthet konkurens helyzetben, de a sérülések kisebb aránya is visszavezethető erre. Az ékszerteknős po- 
pulációban tapasztalt nagyobb termetủ egyedek többségi jelenléte az eredetükkel magyarázható, de a fiatal vörösfülü ékszerteknősök befogása érdekes kérdéseket vet föl. Miután 2006 óta rendelet tiltja az alfaj behozatalát az Európai Közösségbe, kereskedelme és szaporítása is tiltott, így ezek a példányok vagy illegális szaporításból vagy vadon történt szaporodásból származhatnak. Ez utóbbira utal (de nem bizonyítja) a hím egyedek jelenléte, az udvarló és a tojásrakó viselkedés megfigyelése a vizsgált területen. A holtág különböző szakaszai eltérő napozási lehetőségeket nyújtanak a teknősök számára, ez lehet a magyarázata a térbeli eloszlás különbözőségeinek, amelyet a napozó egyedek és a csapdázott egyedek eloszlása tekintetében tapasztaltunk. Ez a megfigyelésünk nem feltétlenül egyezik Cadi \& Joly (2003) vizsgálatának eredményével, mely szerint a két faj azonos preferenciát mutat a megfelelő napozóhelyek iránt, ami szerintük felveti a konkurencia lehetőségét is. Habár az eddigi hazai természetvédelmi célú kutatásokban ritkán jelentkezett problémaként a közönséges ékszerteknős jelenléte (Farkas et al. 2013, Kovács et al. 2004), érdemes figyelmet szentelni ennek a növekvő jelentöségü jelenségnek.

\section{Irodalomjegyzék}

1143/2014/EU rendelet (2014): Az Európai Parlament és a Tanács 1143/2014/EU rendelete (2014. október 22.) az idegenhonos inváziós fajok betelepítésének vagy behurcolásának és terjedésének megelözéséről és kezeléséről.

Arena, P. C., Steedman, C. \& Warwick, C. (2012): Amphibian and reptile pet markets in the EU: An investigation and assessment. - Animal Protection Agency, $52 \mathrm{p}$.

Cadi, A. \& Joly, P. (2003): Competition for basking places between the endangered European pond turtle (Emys orbicularis) and the introduced red-eared slider (Trachemys scripta elegans). - Can. J. Zool. 81: 1392-1398. doi: https://doi.org/10.1139/z03-108

Cadi, A. \& Joly, P. (2004): Impact of the introduction of the red-eared slider (Trachemys scripta elegans) on survival rates of the European pond turtle (Emys orbicularis). - Biodivers. Conserv. 13: 2511-2518. doi: https://doi.org/10.1023/B:BIOC.0000048451.07820.9c

Farkas, B., Halpern, B., Agócs, P., Dankovics, R., Földi, A., Gulácsi, E., Györffy, Gy., Kalmár, Zs., Kiss, I., Kovács, T., Lovász, Zs. E., Molnár, L., Molnár, T. G., Péchy, T., Somlai, T. \& Torvaji, L. (2013): Conservation activities for European pond turtles (Emys orbicularis) in Hungary. Herpetol. Notes 6: 107-110.

Huxel, G. R. (1999): Rapid displacement of native species by invasive species: effects of hybridization. - Biol. Conserv. 89: 143-152. doi: https://doi.org/10.1016/S0006-3207(98)00153-0

Kovács, T., Anthony, B., Farkas, B. \& Bera, M. (2004): Preliminary results of a long-term conservation project on Emys orbicularis in an urban lake in Budapest, Hungary. - Turtle and Tortoise Newsletter 7: 14-17.

Lowe, S., Browne, M., Boudjelas, S. \& de Poorter, M. (2000): 100 of the world's worst invasive alien species. A selection from the global invasive species database. - Hollands Printing Ltd, New Zealand, $12 \mathrm{p}$. 
Mali, I., Wang, H-H., Grant, W. E., Feldman, M. \& Forstner, M. R. J. (2015): Modeling commercial freshwater turtle production on US Farms for pet and meat markets. - PLOS ONE 10: e0139053. doi: https://doi.org/10.1371/journal.pone.0139053.s001

Mooney, H. A. \& Cleland, E. (2001): The evolutionary impact of invasive species. - Proc. Natl. Acad. Sci. 98: 446-451. doi: https://doi.org/10.1073/pnas.091093398

Perez-Santigosa, N., Díaz-Paniauga, C. \& Hidalgo-Vila, J. (2008): The reproductive ecology of exotic Trachemys scripta elegans in an invaded area of southern Europe. - Aquatic Conserv: Mar. Freshw. Ecosyst. 18: 1302-1310. doi: https://doi.org/10.1002/aqc.974

Sancho, V. \& Lacomba, J. I. (2016): Expansion of Trachemys scripta in the Valencian Community (Eastern Spain). - Proc. Int. Symp. Fresh Turtles Conserv. 1: 41-49.

Shea, K. \& Chesson, P. (2002): Community ecology theory as a framework for biological invasions. - Trends Ecol. Evol. 17: 170-176. doi: https://doi.org/10.1016/S0169-5347(02)02495-3

Valdeón, A. Crespo-Diaz, A., Egaña-Callejo, A. \& Gosá, A. (2010): Update of the pond slider Trachemys scripta (Schoepff, 1792) records in Navarre (Northern Spain), and presentation of the Aranzadi Turtle Trap for its population control. - Aquat. Invasions 5: 297-302. doi: http://dx.doi. org/10.3391/ai.2010.5.3.07

Vitousek, P. M., Mooney, H. A., Lubchenco, J. \& Melillo, J. M. (1997): Human domination of earth's ecosystems. - Science 277: 494-499. doi: http://doi.org/10.1126/science.277.5325.494 


\title{
Population features of invasive turtle species and European pond turtle in Holt-Maros
}

\author{
Nóra Molnár, Zsolt Fekete and Alexandra Bokis \\ University of Szeged, Department of Ecology \\ H-6726 Szeged, Középfasor 52., Hungary \\ e-mail: molnarn@bio.u-szeged.hu
}

Surveys of pond turtle population were performed between June and September 2017 in the locally protected backwater of Maros River, Szeged, Hungary. During the visual observation along the backwater, species and positions of basking specimens were recorded. In addition, basking traps were placed at 6 points of the backwater. Carapax and plastron size and body weight were measured, and injuries and anomalies were recorded for each individual captured. All captured pond turtles were individually marked and released. During visual observation of basking individuals, 59 pond turtles and 65 invasive turtles were recorded. With basking traps, 75 pond turtles and 69 invasive turtles were captured during the 2,5 month collecting period. Three invasive species were found in the study area: majority of invasives was common slider (Trachemys scripta - including all the three subspecies), and 1-1 specimen of map turtle (Graptemys sp.) and chinese stripe-necked turtle (Mauremys sinensis) were captured, respectively. Regarding the sex ratio of common sliders and pond turtles, females dominated in both species (female/male: 2,0 and 1,46, repectively). Size difference between the two species is known but also size-distributions were different. Larger size classes of females dominated in common slider population but among pond turtle females usually the medium-sized individuals dominated. Number of injured individuals was higher among pond turtles $(20 \%)$ then among common sliders $(11,9 \%)$. Injuries were more common among females: $31,7 \%$ of captured female pond turtles were injured. Comparison of data from visual observation of basking individuals and from trapping resulted in different spatial distribution. This is probably due to different basking opportunities at different sections of the backwater.

Keywords: Emys orbicularis, common slider, invasive species, size-distribution 